\title{
Persepsi Masyarakat Kelurahan Nan Balimo Kota Solok terhadap pelaksanaan fungsi kehumasan pada bagian Humas Sekretariat Daerah Kota Solok
}

Nurul Afriyanti ${ }^{1}$, Sulastri Sulastri ${ }^{2}$, Ahmad Sabandi $^{3}$, Hanif Al Kadri ${ }^{4}$

1,2,3,4 Administrasi Pendidikan, Universitas Negeri Padang

Nurul Afriyanti ${ }^{1}$, e-mail: afriyantinuru1055@gmail.com

Sulastri Sulastri ${ }^{2}$ e-mail:sulastri_aip@fip.unp.ac.id

Ahmad Sabandi ${ }^{3}$ e-mail:sabandi@fip.unp.ac.id

Hanif Al Kadri ${ }^{4}$ e-mail:hanifalkadri@fip.unp.ac.id

\begin{abstract}
This research is based on the results of the author's observations on the implementation of public relations functions that are still not running effectively in the public relations section of the Solok City Regional Secretariat. The purpose of this research is to get information about the public perception of Nan Balimo Kota Solok village towards the implementation of public relation functions in the public relations section of the Solok City Regional Secretariat seen from indicators of creating a conducive atmosphere, effective communication, developing a positive organizational image, public persuasion, and fostering good relations with the public. This type of research is descriptive with quantitative methods. The population of this study was 2,502 people in Nan Balimo Village, so the sample was 259 respondents. Sample withdrawal in this study was proportional simple random sampling technique. Data collection in this research using questionnaires with likert scale has been tested validity and reliability. The average formulation is used in processing data in this research. The data showed the public response regarding the implementation of public relations function of the Solok City regional secretariat from: (1) creating a conducive atmosphere to get an average score of 3.90 that got a good category;(2) effective communication gets an average score of 3.88 which gets a good category; (3) develop a positive organizational image with an average score of 3.81 thats gets a good category; (4) public persuasion getas an average score of 3.79 which gets a good category; (5) fostering good relations with the public gets an average score of 3.76 which gets a good category. Overall, the public perception of Nan Balimo Kota Solok village towards the implementation of public relations function in the public relations section of the Solok City Regional Secretariat received an average score of 3.83 which got a good category.
\end{abstract}

\begin{abstract}
Abstrak
Penelitian ini didasarkan oleh hasil pengamatan penulis mengenai pelaksanaan fungsi kehumasan yang masih kurang berjalan dengan efektif di bagian humas Sekretariat Daerah Kota Solok.Tujuan dari penelitian ini adalah untuk mendapatkan informasi tentang Persepsi masyarakat kelurahan Nan Balimo Kota Solok terhadap pelaksanaan fungsi kehumasan pada bagian humas Sekretariat Daerah Kota Solok dilihat dari indikator menciptakan suasana kondusif, komunikasi yang efektif, mengembangkan citra organisasi yang positif, persuasi publik, dan membina hubungan baik dengan publik. Jenis penelitian ini bersifat deskriptif dengan metode kuantitatif.Populasi dari penelitian ini masyarakat kelurahan Nan Balimo Kota Solok yang berjumlah 2.502 orang maka besar sampel yang diambil adalah 259 responden. Penarikan sampel pada penelitian ini teknik Proportional Simple Random Sampling.Pengumpulan data dalam penelitian ini menggunakan angket dengan skala likert telah diuji validitas dan reliabilitasnya.Rumusan rata-rata digunakan dalam mengolah data pada penelitian ini. Data menunjukan tanggapan masyarakat mengenai pelaksanaan fungsi kehumasan humas sekretariat daerah Kota Solok dari : (1) menciptakan suasana kondusif mendapatkan skor rata-rata 3.90yang mendapat kategori baik; (2) komunikasi yang efektif mendapatkan skor rata-rata 3.88 yang mendapat kategori baik; (3) mengembangkan citra organisasi yang positif mendapatkan skor rata-rata 3.81 yang mendapat kategori baik; (4) persuasi publik mendapatka skor rata-rata 3.79 yang mendapat kategori baik; (5) membina hubungan baik dengan publik mendapatkan skor rata-rata 3.76 yang mendapat kategori baik. Secara keseluruhan Persepsi masyarakat kelurahan Nan Balimo Kota Solok terhadap pelaksanaan fungsi kehumasan pada bagian humas Sekretariat Daerah Kota Solok mendapatkan skor rata-rata 3.83 yang mendapat kategori baik.
\end{abstract}

Kata Kunci:Persepsi, Fungsi hubungan masyarakat 
How to Cite: NurulAfriyanti1, Sulastri Sulastri2, Ahmad Sabandi 3, Hanif Al Kadri 4, 2021.Persepsi Masyarakat kelurahan Nan Balimo Kota Solok terhadap pelaksanaan fungsi kehumasan pada bagian humas Sekretariat Daerah Kota Solok. Journal Educational Administrasi and Leadership, Vol (N): pp.XX-XX,DOI:10.24036/XXXXXXXXXX-X-XX

This is an open access article distributed under the Creative Commons 4.0 Attribution License, which permits unrestricted use, distribution, and reproduction in any medium, provided the original work is properly cited @2020 by author

\section{Pendahuluan}

Adapun di lingkungan instansi pemerintah yang berhubungan dengan masyarakat yang disebut humas pemerintah merupakan lembaga humas yang berfungsi melaksanakan tugas pada bidang komunikasi dan informasi.Dalam menciptakan hubungan yang harmonis antara pemerintah dan masyarakat humas harus menjalankan fungsinya secara efektif dan efisien.

Keberadaan humas merupakan hal yang terpenting bagi sebuah organisasi, baik organisasi pemerintah maupun swasta (Hong, 2013). Sangat penting bagi suatu organisasi untuk dapat mengoptimalkan fungsi humas tersebut agar dapat meningkatkan kepercayaan publik terhadap organisasi. Pelaksanaan fungsi humas yang efektif dan efisien akan memberikan kelancaran terhadap pelaksanaan tugas-tugas organisasi lainnya.

Adapun beberapa indikator dalam pelaksanaan fungsi kehumasan adalah sebagai berikut:

a. Menciptakan suasana kondusif adalah terciptanya kondisi yang kondusif dengan bermoral dan tingkah laku yang baik dari praktis humas. Bertrand N Canfield (Nesia A, 2014)

b. Komunikasi yang efektif adalah dalam kegiatan komunikasi dapat mengubah sikap, sudut pandang, dan tingkah laku komunikan. Effendi (Effendi, 2011)

c. Mengembangkan citra organisasi yang positif adalah upaya bagaimana agar pihak lain dapat melihat suatu lembaga, organisasi, perseorangan atau sebuah aktifitas dengan pandangan positif. Katz (Soemirat, 2012)

d. Persuasi publik adalah bentuk komunikasi yang dilakukan dalam rangka mempengaruhi opini publik. Cutlip and Center (Nesia A, 2014)

e. Membina hubungan baik dengan publik adalah dengan adanya hubungan baik antar suatu organisasi dengan masyarakat dalam pencegahan rintangan psikologis yang timbul dari pihak lain. Effendi (Effendi, 2006).

Permasalahan yang penulis amati dan lihat di lapangan ialah kurang terciptanya suasana yang kondusif antara masyarakat dan pemerintah, sering terjadinya ketidaktepatan dalam penyampaian berita ataupun informasi, kurangnya usaha humas dalam mengembangkan citra positif pemerintah, humas yang kurang mampu mempengaruhi opini publik, kurang terciptanya hubungan baik antara humas pemerintah dengan masyarakat.

Berdasarkan pemaparan diatas maka yang akan diteliti yaitu : 1) bagaimanakah persepsi masyarakat kelurahan Nan Balimo Kota Solok terhadap pelaksanaan fungsi humas dalam hal menciptakan suasana yang kondusif? 2) bagaimanakah persepsi masyarakat kelurahan Nan Balimo Kota Solok terhadap pelaksanaan fungsi humas dalam hal komunikasi yang efektif? 3)bagaimanakah persepsi masyarakat kelurahan Nan Balimo Kota Solok terhadap pelaksanaan fungsi humas dalam hal mengembangkan citra organisasi yang positif? 4)bagaimanakah persepsi masyarakat kelurahan Nan Balimo Kota Solok terhadap pelaksanaan fungsi humas dalam hal persuasi publik? 5)bagaimanakah persepsi masyarakat kelurahan Nan Balimo Kota Solok terhadap pelaksanaan fungsi humas dalam hal membina hubungan baik dengan publik?.

\section{Metode Penelitian}

Tempat yang dilakukan oleh peneliti ialah kelurahan Nan Balimo.Jenis riset ialah kuantitatif. Masyarakat kelurahan Nan Balimo Kota Solok yang berjumlah 2.502 orang yang dijadikan populasinya dengan sampel 259 responden serta memakai teknik proportional simple random sampling. Riset ini memakai angket berdasarkan skala likert yang telah dilakukan pengujian validitas dan reliabilitasnya, rumus rata-rata yang dilakukan untuk memperoleh data hasil penelitian.

\section{Hasil dan Bahasan}

\subsection{Hasil}

Berdasarkan hasil penelitian berikut dijelaskan satu persatu menurut indikator peneliti:

Secara keseluruhan skor rata-rata tentang persepsi masyarakat kelurahan Nan Balimo Kota Solok terhadap pelaksanaan fungsi kehumasan dilihat dalam hal: a) menciptakan suasana yang kondusif adalah 
3.90 berkategori baik, hal ini diartikan bahwa pelaksanaan fungsi kehumasan pada bagian humas Sekretariat Daerah Kota Solok telah terlaksana dengan baik dan hanya perlu untuk ditingkatkan. b) komunikasi yang efektif adalah 3.88 berkategori baik, hal ini dikatakan bahwa pelaksanaan fungsi kehumasan pada bagian humas Sekretariat Daerah Kota Solok sudah terlaksana dengan baik dan hanya perlu untuk ditingkatkan. c) mengembangkan citra organisasi yang positif adalah 3.81 berkategori baik, hal ini dikatakan bahwa pelaksanaan fungsi kehumasan pada bagian humas Sekretariat Daerah Kota Solok sudah terlaksana dengan baik dan hanya perlu untuk ditingkatkan. d) persuasi publik adalah 3.79 berkategori baik, hal ini dikatakan bahwa pelaksanaan fungsi kehumasan pada bagian humas Sekretariat Daerah Kota Solok sudah terlaksana dengan baik dan hanya perlu untuk ditingkatkan. e) membina hubungan yang baik dengan publik adalah 3.76 berkategori baik, hal ini dikatakan bahwa pelaksanaan fungsi kehumasan pada bagian humas Sekretariat Daerah Kota Solok sudah terlaksana dengan baik dan hanya perlu untuk ditingkatkan.

\subsection{Pembahasan}

Berdasarkan hasil dari penelitian persepsi masyarakat kelurahan Nan Balimo Kota Solok terhadap pelaksanaan fungsi kehumasan pada bagian humas Sekretariat Daerah Kota Solok dilihat dalam hal menciptakan suasana kondusif pada taraf baik dengan rata-rata 3.90, komunikasi yang efektif pada taraf baik dengan rata-rata 3.88, mengembangkan citra organisasi yang positif pada taraf baik dengan rata-rata 3.81 , persuasi publik pada taraf baik dengan rata-rata 3.79 , membina hubungan yang baik dengan publik pada taraf baik dengan rata-rata 3.76 .

a. Menciptakan suasana kondusif

Pengolahan hasil data penelitian menunjukkan, tanggapan masyarakat terhadap pelaksanaan fungsi kehumasan pada bagian humas Sekretariat Daerah Kota Solok dilihat dalam hal menciptakan suasana kondusif mendapatkan rata-rata 3.90 berkategori baik dengan 9 item pernyataan. Dilihat dari segi menciptakan suasana kondusif yang tertinggi yaitu terdapat pada pernyataan "Memahami perbedaan pandangan di tengah masyarakat" dengan skor rata-rata 4,20. Berarti telah dilakukan dengan baik. Sedangkan item yang terendah pada pernyataan "Menjelaskan isu negatif tentang pemko yang ada ditengah masyarakat" dengan skor rata-rata 3.58. Artinya dilihat dari segi menciptakan suasana kondusif pelaksanaan fungsi kehumasan pada bagian humas Sekretariat Daerah Kota Solok sudah terlaksana dengan baik.

b. Komunikasi yang efektif

Pengolahan hasil data penelitian menunjukkan bahwa tanggapan masyarakat terhadap pelaksanaan fungsi kehumasan pada bagian humas Sekretariat Daerah Kota Solok dilihat dalam hal komunikasi yang efektif mendapatkan rata-rata 3.88 berkategori baik dengan 9 item pernyataan. Dilihat dari segi komunikasi yang efektif yang tertinggi yaitu terdapat pada pernyataan "Menjadi penerjemah yang baik terhadap kebijakan pemerintah" dengan skor rata-rata 4,21. Sedangkan item yang terendah terdapat pada pernyataan "Menggunakan media yang tepat dalam menyampaikan informasi" dengan skor ratarata 3,62. Artinya dilihat dari segi komunikasi yang efektif pelaksanaan fungsi kehumasan pada bagian humas Sekretariat Daerah Kota Solok sudah terlaksana dengan baik.

c. Mengembangkan citra organisasi yang positif

Pengolahan hasil data penelitian menunjukkan, tanggapan masyarakat terhadap pelaksanaan fungsi kehumasan pada bagian humas Sekretariat Daerah Kota Solok dilihat dari mengembangkan citra organisasi yang positif mendapat skor rata-rata 3.81 yaitu berkategori baik dengan 9 item pernyataan. Dilihat dari segi mengembangkan citra organisasi yang positif yang tertinggi yaitu terdapat pada item pernyataan "Melakukan dokumentasi terhadap kegiatan-kegiatan yang dilaksanakan pemko" dengan skor rata-rata 4,01. Sedangkan item yang terendah dalam mengembangkan citra organisasi yang positif yaitu "Menyebarluaskan melalui sarana kehumasan keberhasilan-keberhasilan yang telah dicapai pemerintah" dengan skor rata-rata 3.43. Artinya dilihat dari segi mengembangkan citra organisasi yang positif pelaksanaan fungsi kehumasan pada bagian humas Sekretariat Daerah Kota Solok sudah terlaksana dengan baik.

d. Persuasi Publik

Pengolahan hasil data penelitian menunjukkan, tanggapan masyarakat terhadap pelaksanaan fungsi kehumasan pada bagian humas Sekretariat Daerah Kota Solok dilihat dari persuasi publik mendapat skor rata-rata 3,79 yaitu berkategori baik dengan 8 item pernyataan. Dilihat dari segi persuasi publik yang tertinggi yaitu terdapat pada item pernyataan " Memberikan pemahaman kepada masyarakat tentang program-program yang dilakukan pemerintah" dengan skor rata-rata 4,19. Sedangkan item yang terendah dalam persuasi publik yaitu "Pegawai humas mampu mengarahkan opini masyarakat terhadap 
pemerintah" dengan skor rata-rata 3,51. Artinya dilihat dari segi persuasi publik pelaksanaan fungsi kehumasan pada bagian humas Sekretariat Daerah Kota Solok sudah terlaksana dengan baik.

e. Membina hubungan baik dengan publik

Pengolahan hasil data penelitian menunjukkan, tanggapan masyarakat terhadap pelaksanaan fungsi kehumasan pada bagian humas Sekretariat Daerah Kota Solok dilihat dari membina hubungan baik dengan publik mendapat skor rata-rata 3,76 yaitu berkategori baik dengan 9 item pernyataan. Dilihat dari segi membina hubungan baik dengan publik yang tertinggi yaitu terdapat pada item pernyataan "Menampung aspirasi serta keinginan masyarakat" dengan skor rata-rata 4,19. Sedangkan item yang terendah pada membina hubungan baik dengan publik yaitu "Memberikan pelayanan yang maksimal" dengan skor rata-rata 3,64. Artinya dilihat dari segi membina hubungan baik dengan public pelaksanaan fungsi kehumasan pada bagian humas Sekretariat Daerah Kota Solok sudah terlaksana dengan baik.

\section{Kesimpulan}

Kesimpulan hasil dari penelitian mengenai Persepsi masyarakat kelurahan Nan Balimo Kota Solok terhadap pelaksanaan fungsi kehumasan pada bagian humas Sekretariat Daerah Kota Solok dilihat dalam hal menciptakan suasana kondusif berkategori baik mendapatkan skor rata-rata 3,90. Komunikasi yang efektif berkategori baik mendapatkan skor rata-rata 3,88. Mengembangkan citra organisasi yang positif berkategori baik mendapatkan skor rata-rata 3,81. Persuasi publik berkategori baik mendapatkan skor rata-rata 3,79. Membina hubungan baik dengan publik berkategori baik mendapatkan skor rata-rata 3,76. Secara umum persepsi masyarakat terhadap pelaksanaan fungsi kehumasan pada bagian humas Sekretariat Daerah Kota Solok sudah berkategori baik mendapatkan skor rata-rata 3,83.

Jadi dari kesimpulan diatas, tentang persepsi masyarakat kelurahan Nan Balimo Kota Solok terhadap pelaksanaan fungsi kehumasan pada bagian humas Sekretariat Daerah Kota Solok bisa dikatakan sudah terlaksana dengan baik sesuai dengan angket yang diisi oleh masyarakat untuk itu masih perlu adanya peningkatan dari bagian humas Sekretariat Daerah Kota Solok dalam menunjang peningkatan pelaksanaan fungsi kehumasan dalam mencapai kategori sangat baik agar pelaksanaan fungsi kehumasan dapat terlaksana dengan lebih optimal.

\section{Daftar Rujukan}

Effendi, O. . (2006). Hubungan Masyarakat suatu Studi Komunikologis. Bandung: PT.Remaja Rosdakarya.

Effendi, O. . (2011). Ilmu Komunikasi. Bandung: PT.Remaja Rosdakarya.

Hong, H. (2013). Government websites and social media's influence on government public relationship.

Nesia A. (2014). Dasar-dasar Humas. Yogyakarta: Graha Ilmu.

Soemirat, S. . (2012). Dasar-dasar Public Relation. Bandung: PT.Remaja Rosdakarya. 